\title{
PRETERM LABOR CONDITIONS OF WOMEN WITH HIGH-RISK PREGNANCY AND RELATED FACTORS: A RETROSPECTIVE COHORT STUDY
}

\author{
YÜKSEK RISKLI HAMILELERDE ERKEN DOĞUM VE ILGILI FAKTÖRLER: RETROSPEKTIF \\ KOHORT ÇALIŞMASI
}

\author{
Seher PALANBEK YAVAŞ ${ }^{1}$ (D), Caner BAYSAN² (D) \\ ${ }^{1}$ Istanbul University, Istanbul Faculty of Medicine, Department of Public Health, Istanbul, Turkey \\ ${ }^{2}$ Ankara University, School of Medicine, Department of Internal Medicine, Department of Public Health, Ankara, Turkey
}

ORCID IDs of the authors: S.P.Y. 0000-0002-8113-0477; C.B. 0000-0002-7675-1391

Cite this article as: Palanberk Yavas S, Baysan C. Preterm labor conditions of women with high-risk pregnancy and related factors: a retrospective cohort study. J Ist Faculty Med. Published online March 1, 2022. doi: 10.26650/IUITFD.960284

\section{ABSTRACT}

Objective: High-risk pregnancy is a situation associated with pregnancy involving a real or potential risk for the health and well-being of the mother and the fetus. Our study aimed to examine the preterm labor conditions of pregnant women followed up at a high-risk pregnancy outpatient clinic and related factors.

Material and Methods: Designed as a retrospective cohort study, the study was carried out with the participation of 293 pregnant women who presented to a high-risk pregnancy outpatient clinic in the Batman province of Turkey and were followed up between March 2017 and January 2019.

Results: The top three high-risk conditions determined in the pregnant women were pregnancy over the age of $35(n=83,28.3 \%)$, pregnancy in a shorter interval than two years $(n=71,24.2 \%)$ and consanguineous marriage $(n=60,20.5 \%)$, respectively. Twentypoint-one percent $(n=59)$ of the pregnant women had preterm labor. It was determined that the rates of caesarean section births and births at a private hospital among the pregnant women who had preterm labor were significantly higher in comparison to the pregnant women who gave birth at term $(p=0.001, p=0.037$, respectively). It was determined that the risk of preterm labor increased $O R=5.6(1.2-25.6)$ times in the pregnant women with anemia, $O R=12.5(1.3-122.7)$ times in those with intrauterine fertilization and $O R=32.6$ (3.2-332.5) times in those with multiple pregnancies.

Conclusion: Anemia, multiple pregnancy and intrauterine fertilization increase the risk of preterm labor. Quality prenatal care services are important in terms of protecting the health of the mother and the newborn.

Keywords: Preterm birth, risk factors, anemia, multiple pregnan$c y$, intrauterine fertilization

\section{ÖZET}

Amaç: Riskli gebelik annenin ve fetüsün sağlığı veya iyiliği için gerçek veya potansiyel bir tehlikeye sahip hamilelikle ilişkili bir durumdur. Çalışmamızda riskli gebelik polikliniğinde takibi yapılan gebelerin preterm eylem durumu ve ilişkili faktörlerin incelenmesi amaçlanmıştır.

Gereç ve Yöntem: Retrospektif kohort olarak tasarlanan bu çalışma Batman ilinde (Türkiye) riskli gebe polikliniğine başvuran Mart 2017- Ocak 2019 tarihleri arasında takibi yapılan 293 gebe ile gerçekleştirilmiştir.

Bulgular: Gebelerde tespit edilen ilk üç risk durumu sırasıyla 35 yaş üzeri gebelik ( $n=83, \% 28,3)$, iki yıldan kısa aralıklı gebelik ( $n=71, \% 24,2)$, akraba evliliği $(n=60, \% 20,5)$ şeklindedir. Riskli gebelerin \%20,1'inde $(n=59)$ preterm eylem gerçekleşmiştir. Preterm eylem gerçekleşen gebelerin miadında doğum yapan gebelere göre sezaryen doğum ve özel hastanede doğum yapma durumu istatistiksel olarak fazla olduğu tespit edilmiştir (sırasıyla $p=0,001, p=0,037)$. Preterm eylem riski değerlendirildiğinde, anemisi olan gebelerde $\mathrm{OR}=5,6(1,2-25,6) \mathrm{kat}$, intrauterin fertilizasyon olan gebelerde $\mathrm{OR}=12,5(1,3-122,7)$ kat, çoğul gebelerde $\mathrm{OR}=32,6(3,2-332,5)$ kat arttığı tespit edilmiştir.

Sonuç: Anemi, multiparite ve intrauterin fertilizasyon preterm eylem riskini artırmaktadır. Kaliteli doğum öncesi bakım hizmetleri gebe ve bebek sağlığını korumada önemlidir..

Anahtar Kelimeler: Preterm doğum, risk faktörleri, anemi, çoğul gebelik, intrauterin fertilizasyon

Corresponding author/iletişim kurulacak yazar: canerbaysan@gmail.com

Submitted/Başvuru: 01.07.2021 • Revision Requested/Revizyon Talebi: 11.10.2021 •

Last Revision Received/Son Revizyon: 20.10.2021 • Accepted/Kabul: 20.01.2022 • Published Online/Online Yayın: 01.03 .2022 


\section{INTRODUCTION}

Pregnancy is a process in which women experience changes brought about by new biological, physiological and sociological conditions (1). The World Health Organization (WHO) reported that in 2017, 295,000 women (approximately 810 women per day) lost their lives due to preventable causes associated with pregnancy and birth, and $94 \%$ of these deaths occurred in countries with lower and lower-middle income levels (2). In the High-Risk Pregnancy Management Guide prepared by the Turkish Ministry of Health, risk assessment is made under the headings of medical history (e.g., cardiovascular diseases, gynecological diseases, endocrine diseases), obstetric history (e.g., previous uterine surgery, pelvic mass, recurrent miscarriage, eclampsia-preeclampsia) and evaluation of current pregnancy (e.g., younger than 18 years old, older than 35 years old, Rh/rh incompatibility, multiple pregnancy, pregnancy in a period of shorter than two years after previous pregnancy). In the case of the presence of these conditions determined in this context in the pregnant woman, she is regarded as carrying a high risk and is referred to a hospital where an obstetrician is available (3). An important condition that may occur in high-risk pregnancies and affect the fetus is preterm labor. Approximately $11 \%$ of the births (around 15 million babies) in the world per year are early-term births (4). Many countries have reported an increase in the rate of early term births in the last 20 years, and this general trend has been verified by global research conducted by the $\mathrm{WHO}(5,6)$. The prevalence of preterm births in Turkey was determined to be around $12 \%$ (7). Compared to the ones born at term, premature babies are at a higher risk during their lifetime in terms of various disorders, including neurodevelopmental disorders, gastrointestinal complications, cerebral palsy, sensory deficiencies, learning difficulties, and respiratory diseases (8).

In this study, it was aimed to determine the causes of preterm labor in high-risk pregnant women. This study had two main hypotheses. The first hypothesis was that the presence of anemia in pregnant women increases the risk of preterm labor. The second was that the risk of preterm labor is higher in pregnancies induced by assistive reproductive techniques.

\section{MATERIALS AND METHODS}

This is a retrospective cohort study. The Turkish Ministry of Health has determined risk factors for pregnant women and created a high-risk pregnancy identification form. The population of this study consisted of pregnant women who presented to a high-risk pregnancy outpatient clinic located in the Batman province in Turkey between March 2017 and January 2019. It was determined that 298 pregnant women presented to the clinic between the specified dates. The inclusion criterion was determined as meeting at least one of the three criteria determined by the Turkish Ministry of Health (medical history, obstetric history, and evaluation of current pregnancy) (Table 1). Pregnant women who were not followed-up (moving to another city, failure to attend clinic follow-up) and those whose pregnancy resulted in a miscarriage were excluded from the study. To elaborate, three of the pregnant women who presented to the high-risk pregnancy outpatient clinic were out of the scope of the study due to moving, one was not attending her follow-up, and one had a miscarriage on the $81^{\text {st }}$ day of her gestation. The study protocol was approved by the Batman State Hospital Ethics Committee (Date: 06.10.2019, No: 200)

The minimum required sample size for this study, which was planned to assess the risk of preterm labor in highrisk pregnant women, was calculated using the $\mathrm{G}^{\star}$ Power program. A logistic regression analysis, which is a method in the Z-test family, was conducted for the calculation. Based on the result of the study by Rahman et al., with an alpha $(\alpha)$ error margin or 0.05 and an estimated power of $80 \%$, the minimum required sample size was found as 148 participants (9).

\section{Variables}

All data for the study were obtained from the records of the high-risk pregnancy outpatient clinic. The risk assessment of the pregnant women was made under three categories determined by the Ministry of Health (medical history, obstetric history, and evaluation of current pregnancy). Seventy-two risk factors in total were inquired about, 19 of which were in the medical history, 17 in the obstetric history and 36 in the evaluation of the current pregnancy. Additionally, information regarding the age of the pregnant women, their parity, gravidity and miscarriage status, vitamin D and iron supplementation status, $\mathrm{Td}$ vaccination status and the place and method of birth (vaginal, C/S) was collected. The number of pregnancy follow-ups were calculated over the individuals' visits to the outpatient clinic. The period of pregnancy at labor was calculated according to the time difference between the pregnant woman's last date of menstruation and the date of labor. The pregnant women whose calculated period was $<37$ weeks were evaluated as preterm labor.

\section{Statistical analysis}

The statistical analyses of the study were performed with the Statistical Package for the Social Sciences software, version 25.0 (SPSS). Frequencies and percentages were used for descriptive information on the categorical variables, and means and standard deviations were used for the numerical data that displayed a normal distribution, while the numerical data that did not display a normal distribution is represented by medians $\left(25^{\text {th }}\right.$ percentile- $75^{\text {th }}$ percentile). The normality of the distribution 
Table 1: High-risk pregnancy definition criteria for pregnant women of the Ministry of Health

\begin{tabular}{|c|c|c|c|}
\hline Medical history & Obstetric history & Current pregnancy & \\
\hline Cardiovascular disease & Uterine surgery & Under 18 years old & Trauma during pregnancy \\
\hline Gynecological disease & $\begin{array}{l}\text { Pelvic mass, myoma, } \\
\text { uterine malformation }\end{array}$ & Over 35 years old & Severe infection anemia \\
\hline Diabetes mellitus & Recurrent miscarriage & Rh incompatibility & Commandment \\
\hline Endocrine disease & Low birth weight & Multiple pregnancies & Body mass index $>30 \mathrm{~kg} / \mathrm{m}^{2}$ \\
\hline Epilepsy & Macrosomic baby history & $\begin{array}{l}\text { Pregnancy more than two } \\
\text { years }\end{array}$ & Body mass index $<18 \mathrm{~kg} / \mathrm{m}^{2}$ \\
\hline $\begin{array}{l}\text { Cerebrovascular and } \\
\text { neurological disease }\end{array}$ & Stillbirth, newborn death & Smoking and alcohol use & $\begin{array}{l}\text { Abnormal pregnancy after } \\
\text { infertility }\end{array}$ \\
\hline Psychiatric disease & Preeclampsia or eclampsia & Grand multiparity & Pap smear $(+)$ \\
\hline Chronic hypertension & Preterm labor & $\begin{array}{l}\text { Gestational diabetes } \\
\text { mellitus }\end{array}$ & Cystitis \\
\hline Respiratory system disease & Postterm birth & Placenta previa & $\begin{array}{l}\text { Intrauterine growth } \\
\text { restriction }\end{array}$ \\
\hline Renal disease & Baby with anomaly & Venous thromboembolism & $\begin{array}{l}\text { Inconsistency of uterus size } \\
\text { with } 80^{\text {th }} \text { gestational week }\end{array}$ \\
\hline Hematological disease & $\begin{array}{l}\text { Gestational diabetes } \\
\text { mellitus }\end{array}$ & Heir & Phenylketonuria \\
\hline Infectious disease & Venous thromboembolism & $\begin{array}{l}\text { Polyhydramnios- } \\
\text { oligohydramnios }\end{array}$ & $\begin{array}{l}\text { Intrauterine device and } \\
\text { pregnancy }\end{array}$ \\
\hline Rheumatological disease & Ectopic pregnancy & Fetus with abnormality & $\begin{array}{l}\text { Pregnancy following tube } \\
\text { ligation }\end{array}$ \\
\hline Venous thromboembolism & Rh incompatibility & Cervical insufficiency & Threat of miscarriage \\
\hline Neoplasms & $\begin{array}{l}\text { Antepartum and } \\
\text { postpartum bleeding } \\
\text { history }\end{array}$ & Vaginal bleeding & Gestational hypertension \\
\hline Orthopedic disorder & Difficult and intrusive birth & Preeclampsia or eclampsia & Height less than $150 \mathrm{~cm}$ \\
\hline Consanguineous marriage & $\begin{array}{l}\text { Placenta previa, abruptio } \\
\text { placentae }\end{array}$ & $\begin{array}{l}\text { Surgical intervention during } \\
\text { pregnancy }\end{array}$ & $\begin{array}{l}\text { Pelvic mass, myoma, or } \\
\text { uterine malformation }\end{array}$ \\
\hline Drug use and addiction & & $\begin{array}{l}\text { Hyperemesis gravidarum } \\
\text { requiring hospitalization }\end{array}$ & \\
\hline Low socioeconomic status & & Preterm labor & \\
\hline
\end{tabular}

of the continuous variables were tested by using visual (histogram and probability charts) and analytical (Kolmogorov-Smirnov Test) methods. In the comparison of the categorical variables in independent groups, Pearson's chi-squared test or Fisher's exact test was used. In the comparison of two independent groups, Student's t-test was employed for the variables with normal distribution, while Mann-Whitney $U$ Test was used for those without normal distribution. The variables that were found to be statistically significant $(p<0.05)$ or $p<0.200)$ were included in the logistic regression model. In the logistic regression model, the Enter and Backward methods were used. In the model, the correction was made according to age.
The results were evaluated in a 95\% confidence interval by accepting an alpha error of 0.05 .

\section{RESULTS}

The mean age of the 293 pregnant women who were included in the study was $29.6 \pm 6.4$ years, and their ages ranged between 16 and 52 years. The descriptive characteristics of the pregnant women are presented in Table 2. Seven (2.4\%) out of the 293 pregnancies resulting in live births were twin pregnancies. Ninety-seven-point-six percent $(n=286)$ of the pregnant women were taking iron supplements, and $79.5 \%(n=233)$ were taking vitamin $D$ 
Table 2: Distribution of the characteristics of the pregnant women

\begin{tabular}{lc}
\hline & Number (\%) \\
Birth & \\
At term & $234(79.9)$ \\
Preterm & $59(20.1)$ \\
Birth method & \\
$\quad$ Vaginal Birth & $259(88.4)$ \\
C/S & $34(11.6)$ \\
Sex of the baby born ( $\mathbf{n}=303)$ & \\
$\quad$ Girl & $145(47.9)$ \\
$\quad$ Boy & $158(52.1)$ \\
Place of birth & \\
$\quad$ State hospital & $174(59.4)$ \\
Private hospital & $119(40.6)$ \\
Total number of pregnancies & \\
$\quad$ Mean \pm SD & $4.0 \pm 2.5$ \\
$\quad$ Median (Min-Max) & $4.0(1-15)$ \\
Live birth & \\
$\quad$ Mean $\pm S D$ & $3.2 \pm 2.1$ \\
$\quad$ Median (Min-Max) & $3.0(0-13)$ \\
Miscarriage history & \\
$\quad$ Yes & $126(43)$ \\
$\quad$ No & $167(57)$ \\
Pregnancy follow-up number & \\
$\quad<4$ follow-ups & $56(19.1)$ \\
$\geq 4$ follow-ups & $237(80.9)$ \\
\hline
\end{tabular}

supplements. It was observed that $9.9 \%(n=29)$ of the pregnant women had never been vaccinated against tetanus.

According to the results of the analysis on the medical histories of the pregnant women, $8.9 \%(n=26)$ had endocrine diseases, $2.0 \%(n=6)$ had chronic respiratory diseases, $1.7 \%(n=5)$ had diabetes, $1.4 \%(n=4)$ had cardiovascular diseases, $1.4 \%(n=4)$ had rheumatic diseases, 1.0\% $(n=5)$ had hypertension, and $0.3 \%(n=1)$ had epilepsy. Twenty-point-five percent $(n=60)$ of the pregnant women reported that they had a consanguineous marriage. It was also determined that $4.4 \%(n=13)$ of the pregnant women had a low socioeconomic level.

According to the results of the analysis on the obstetric histories of the pregnant women, none of them had a history of uterine surgery, low birth weight, fetal macrosomia, post-term birth, antepartum and postpartum birth, venous thromboembolism, difficult and interventional birth, placenta previa, or abruptio placentae. It was observed that $0.3 \%(n=1)$ had a pelvic mass, myoma, uterine malformation, $0.3 \%(n=1)$ had a baby with a history of anomaly, $0.7 \%(n=2)$ had a history of gestational diabetes, $0.7 \%(n=2)$ had eclampsia-preeclampsia, $1 \%(n=3)$ had a history of preterm labor, $4.8 \%(n=14)$ had a history of still birth or newborn morbidity, $6.8 \%(n=20)$ had a history of recurrent miscarriage, and $13.7 \%(n=40)$ had a history of ectopic pregnancy.

In the analysis on the current pregnancies of the participants, it was determined that there was no case of fetal anomaly, gestational diabetes, cervical failure, eclampsia or preeclampsia, surgical intervention during pregnancy, severe infection, early membrane rupture, abnormal pap smear, intrauterine growth restriction (IUGR), phenylketonuria, intrauterine device (IUD) pregnancy, pregnancy following tube ligation, height less than $150 \mathrm{~cm}$, pelvic mass, myoma, or uterine malformation. Zero-point-three percent $(n=1)$ of the pregnant women had a body mass index of $<18 \mathrm{~kg} / \mathrm{m}^{2}, 0.3 \%(\mathrm{n}=1)$ had experienced a trauma during pregnancy, $0.7 \%(n=2)$ had polyhydramnios-oligohydramnios, $0.7 \%(n=2)$ had vaginal hemorrhage, $0.7 \%$ $(n=2)$ had hyperemesis gravidarum that required hospitalization, and $0.7 \%(n=2)$ had a risk of miscarriage. Moreover, $1.7 \%(n=5)$ had placenta previa, $1.7 \%(n=5)$ had post-infertility pregnancy, $2.0 \%(n=6)$ had preterm labor, $2.4 \%(n=7)$ had pregnancy before 18 years of age, $2.4 \%$ $(n=7)$ had a multiple pregnancy, $2.7 \%(n=8)$ had anemia, $5.5 \%(n=16)$ had varicose veins, $9.6 \%(n=28)$ had the habit of smoking, $19.8 \%$ ( $n=58$ ) had grand multiparity, $24.2 \%$ $(n=71)$ had a pregnancy interval of shorter than two years, and $28.3 \%(n=83)$ had pregnancy over the age of 35 years.

It was determined that the frequency of use of the $\mathrm{C} / \mathrm{S}$ birth method was significantly higher in the pregnant women who had preterm labor in comparison to those who gave birth at term $(p=0.001)$. Besides, it was found that the rates of giving birth at a private hospital in the pregnant women who had preterm labor were significantly higher in comparison to the pregnant women who gave birth at term $(p=0.037)$ (Table 3$)$.

Table 3: The relationship of preterm labor condition with the birth method of the pregnant women and the place of birth

\begin{tabular}{lccc}
\hline & $\begin{array}{c}\text { At term } \\
(\mathbf{n}=\mathbf{2 3 4})\end{array}$ & $\begin{array}{c}\text { Preterm } \\
(\mathbf{n}=\mathbf{5 9})\end{array}$ & $\mathbf{P}$ \\
$\begin{array}{l}\text { Birth method } \\
\text { Vaginal }\end{array}$ & $214(82.6)$ & $45(17.4)$ & 0.001 \\
$\quad \mathrm{C} / \mathrm{S}$ & $20(58.8)$ & $14(41.2)$ & \\
$\begin{array}{l}\text { Place of birth } \\
\text { State hospital }\end{array}$ & $146(83.9)$ & $28(16.1)$ & 0.037 \\
$\quad$ Private hospital & $88(73.9)$ & $31(26.1)$ & \\
\hline
\end{tabular}

It was determined that the risk of preterm labor was 5.6 times (1.2-25.6) higher in the pregnant women with anemia, 12.5 times (1.3-122.7) higher in those with intrauterine fertilization and 32.6 times (3.2-332.5) higher in those with multiple pregnancy (Table 4). 
Table 4: Factors affecting preterm labor condition of the pregnant women

\begin{tabular}{|c|c|c|c|c|c|c|c|c|}
\hline \multirow[b]{2}{*}{ Maternal characteristics } & \multirow[b]{2}{*}{$\begin{array}{l}\text { At term } \\
(n=234)\end{array}$} & \multirow[b]{2}{*}{$\begin{array}{c}\text { Preterm } \\
(n=59)\end{array}$} & \multicolumn{2}{|c|}{ Univariate } & \multicolumn{2}{|c|}{$\begin{array}{l}\text { Multiple Logistic } \\
\text { Regression/Model } \\
1\end{array}$} & \multicolumn{2}{|c|}{$\begin{array}{l}\text { Multiple Logistic } \\
\text { Regression/Model } \\
2\end{array}$} \\
\hline & & & $\mathbf{P}$ & $\begin{array}{c}\text { OR } \\
(95 \% \mathrm{Cl})\end{array}$ & $\mathbf{P}$ & $\begin{array}{c}\text { OR } \\
(95 \% \mathrm{Cl})\end{array}$ & $\mathbf{P}$ & $\begin{array}{c}\text { OR } \\
(95 \% \mathrm{Cl})\end{array}$ \\
\hline Age (Mean $\pm S D)$ & $30.0 \pm 6.8$ & $29.6 \pm 6.3$ & 0.663 & & 0.929 & $\begin{array}{c}1 \\
(0.9-1.1)\end{array}$ & & \\
\hline Parity median (25P-75P) & $3(2-5)$ & $4(2-6)$ & 0.503 & & & & & \\
\hline Miscarriage median (25P-75P) & $0(0-1)$ & $0(0-1)$ & 0.460 & & & & & \\
\hline Birth median (25P-75P) & $3(1-4)$ & $3(2-4)$ & 0.472 & & & & & \\
\hline $\begin{array}{l}\text { Smoking } \\
\text { Yes } \\
\text { No (ref) }\end{array}$ & $\begin{array}{c}25(89.3) \\
209(78.9)\end{array}$ & $\begin{array}{c}3(10.7) \\
56(21.1)\end{array}$ & 0.191 & $\begin{array}{c}0.5 \\
(0.1-1.5)\end{array}$ & 0.178 & $\begin{array}{c}0.4 \\
(0.1-1.5)\end{array}$ & & \\
\hline $\begin{array}{l}\text { Low socio-economic status } \\
\text { Yes } \\
\text { No }\end{array}$ & $\begin{array}{c}12(92.3) \\
222(79.3)\end{array}$ & $\begin{array}{c}1(7.7) \\
58(20.7)\end{array}$ & 0.477 & & & & & \\
\hline $\begin{array}{l}\text { Low body mass index } \\
\left(<18 \mathrm{~kg} / \mathrm{m}^{2}\right) \\
\text { Yes } \\
\text { No }\end{array}$ & $\begin{array}{c}1(100) \\
233(79.8)\end{array}$ & $\begin{array}{c}0(0) \\
59(20.2)\end{array}$ & 1.000 & & & & & \\
\hline Obstetric history & & & & & & & & \\
\hline $\begin{array}{l}\text { Preterm birth } \\
\text { Yes } \\
\text { No }\end{array}$ & $\begin{array}{l}2(66.7) \\
232(80)\end{array}$ & $\begin{array}{l}1(33.3) \\
58(20)\end{array}$ & 0.492 & & & & & \\
\hline $\begin{array}{l}\text { In-vitro fertilization } \\
\text { Yes } \\
\text { No (ref) }\end{array}$ & $\begin{array}{c}1(20) \\
233(80.9)\end{array}$ & $\begin{array}{c}4(80) \\
55(19.1)\end{array}$ & 0.006 & $\begin{array}{c}16.9 \\
(154.6)\end{array}$ & 0.036 & $\begin{array}{c}11.7 \\
(1.2-116.8)\end{array}$ & 0.030 & $\begin{array}{c}12.5 \\
(1.3-122.7)\end{array}$ \\
\hline $\begin{array}{l}\text { Multiple pregnancy } \\
\text { Yes } \\
\text { No (ref) }\end{array}$ & $\begin{array}{c}1(14.3) \\
233(81.5)\end{array}$ & $\begin{array}{c}6(85.7) \\
53(18.5)\end{array}$ & $<0.001$ & $\begin{array}{c}26.4 \\
(3.1-223.7)\end{array}$ & 0.004 & $\begin{array}{c}31.2 \\
(3.0-320.8)\end{array}$ & 0.003 & $\begin{array}{c}32.6 \\
(3.2-332.5)\end{array}$ \\
\hline $\begin{array}{l}\text { Anemia } \\
\text { Yes } \\
\text { No (ref) }\end{array}$ & $\begin{array}{c}3(37.5) \\
234(79.9)\end{array}$ & $\begin{array}{c}5(62.5) \\
54(20.1)\end{array}$ & 0.010 & $\begin{array}{c}7.1 \\
(1.7-30.8)\end{array}$ & 0.027 & $\begin{array}{c}5.8 \\
(1.2-27.4)\end{array}$ & 0.027 & $\begin{array}{c}5.6 \\
(1.2-25.6)\end{array}$ \\
\hline
\end{tabular}

Model $1 \mathrm{R}^{2}=0.183$, Model $2 \mathrm{R}^{2}=0.173$

\section{DISCUSSION}

In this study, the prevalence of preterm labor among the pregnant women who were in the risky category determined by the Turkish Ministry of Health was found to be as high as $20.1 \%$. In studies conducted at various centers across Turkey, it has been reported that the incidence of preterm birth ranged between $10 \%$ and $19.1 \%$ (10-12). The incidence of preterm birth across Turkey bears similarity to the incidence of preterm birth in the entire world (11.1\%). This incidence ranges from $5 \%$ to $11 \%$ in European countries $(6.7 \%$ in Spain, $5.9 \%$ in Sweden, 6.6\% in France, $5.5 \%$ in Finland), while it is around $18 \%$ in some African countries $(18.3 \%$ in Kenya, $14.2 \%$ in Tanzania, $12.2 \%$ in Nigeria). Among some Asian countries, this rate is $13.0 \%$ in India, $7.1 \%$ in China and $14.0 \%$ in Bangladesh. More than $60 \%$ of preterm babies were born in South Asia and Sub-Saharan Africa $(6,7,13)$. Preterm birth is also a problem for high-income countries such as the United States (US). According to the Centers for Disease Control and Prevention, one out of every 10 births occurred as preterm birth in 2019 (14). The reason why the prevalence of preterm birth was found to be high in our study may have stemmed from the fact that all pregnant women included in the study were in the risky category, while in the studies mentioned above, pregnant women were included without considering their risk categories. In another study conducted in California, it was determined that women with risk scores $\geq 3.0$ in pre-pregnancy and first trimester training and testing samples had a preterm 
labor rate of about $40 \%$ (15). In a study conducted in New Zealand, it was determined that women with two or three risk factors $(O R=2.87)$ were at a greater risk of preterm labor (16). Comprehensive studies have defined many risk factors for preterm labor $(17,18)$. In addition to maternal demographic characteristics such as ethnic origin, age and socioeconomic status, these include pregnancy characteristics such as multiple pregnancy, shortened cervix and urogenital system infections (19). The risk of preterm labor in pregnant women included in our study was found to be higher in those with anemia, those with intrauterine fertilization and those with multiple pregnancy $(p=0.027$, $p=0.030$ and $p=0.030$ respectively) compared to other pregnant women.

Today, the use of assisted reproductive technologies (ART) is quite widespread. One of the results of the popularity of ART is to make three or more embryo transfers to obtain a higher probability of pregnancy and the consequent progressive increase in the incidence of twin, triplet and multiple pregnancies. High rates of multiple births accompanied by complications of prematurity are well-documented $(20,21)$. According to the National Vital Statistics' report, in the US, preterm birth rates were found as $9.9 \%$ for single births, $57.4 \%$ for twin births and $92.7 \%$ for births involving triplets or more babies (22). In a meta-analysis covering different countries, it was determined that in multiple pregnancies that occurred as a result of in vitro fertilization and intracytoplasmic injection, the highest reported prevalence of preterm birth was observed in Singapore [80.2\% (95\% Cl: 75.3-84.3)], followed by Italy [75.8\% (95\% Cl: 66.0-83.5)], Australia (57.1\% (95\% Cl: 47.2-66.5)], Germany [56.0\% (95\% Cl: 44.0-67.3)] and China [52.8\% (95\% Cl: 48.6-57.1)] (23). In the study conducted by Luke et al. that included a broad population of pregnant women from 14 different cities, the pregnant women who had received IVF treatment had a 1.48 times (95\% Cl 1.37-1.61) higher chance of having a very early preterm birth (22-27 weeks), a 1.52 times $(95 \% \mathrm{Cl} 1.45$ 1.59) higher chance of having an early preterm birth (22-32 weeks) and a 1.48 times (95\% Cl 1.45-1.15) higher chance of having a preterm birth (22-36 weeks) in comparison to other pregnant women (24). In their study carried out in Massachusetts, Stern et al. determined that ART-treated pregnant women had a 1.40 times (adjusted odds ratio [AOR] 1.40, 95\% Cl 1.25-1.50) higher change of preterm labor than other pregnant women (25). Another study identified the rate of preterm births ( $<32$ weeks) in infants born as a result of in vitro fertilization as 2 times higher (AOR, $2.13 ; 95 \% \mathrm{Cl} 1.80-2.52)(26)$. A meta-analysis study reported that in women who got pregnant by receiving IVF or intracytoplasmic sperm injection (ICSI) treatment (singleton pregnancies), the rates of spontaneous preterm labor before 37 weeks and spontaneous preterm labor before 34 weeks increased (respectively, OR 1.75; 95\% Cl, 1.502.03; $\mathrm{l}^{2}=39 \%$ and OR $1.78 ; 95 \% \mathrm{Cl}, 1.03-3.08 ; \mathrm{l}^{2}=6 \%$ ) (27).
Despite the success of mother and child health programs, anemia is still the leading cause of maternal deaths and adverse pregnancy outcomes (e.g., preterm birth, low birth weight) in developing countries. In our study, it was determined that the pregnant women with anemia had a higher risk of preterm labor. Haider et al. determined that the risk of preterm labor increased in pregnant women with anemia by 1.21 times (1.13 to 1.30). Likewise, in another study conducted by Rahman et al., this risk was found to increase by 1.63 times (95\% Cl: 1.33, 2.01), while Rahmati et al. reported an increase in this risk by 1.56 times $(95 \% \mathrm{Cl}: 1.25-1.95)(9,28,29)$. A retrospective cohort study in California observed that the children of pregnant women with anemia were born preterm at higher rates (8.9\% versus $6.5 \%$ adjusted for maternal characteristics and obstetric complications RR 1.3, 95\% Cl: 1.3-1.4) (30). A study in Taiwan revealed that the preterm labor rates of pregnant women with anemia (Hemoglobin level<10.8 g/ dl) increased (adjusted OR: 2.16, 95\% Cl: 1.54-3.03) (31). A randomized-controlled study carried out in South India reported that the preterm labor risk of women with iron deficiency anemia was more than 3 times higher than other pregnant women (RR: 3.46 (1.81-6.61); $p=0.0002$ ) (32).

In a study conducted in Turkey in 2020, the preterm labor rates were found to be significantly higher in pregnant women with anemia compared to pregnant women without anemia $(p<0.05)$ (33). Another study in Turkey (provinces of Rize and Istanbul) found higher rates of preterm labor in pregnant women with lower hemoglobin levels (OR, 2.42; 95\% Cl: 1.07-5.49) (34).

In our study, another factor that increased the risk of preterm labor was identified as multiparity. Muniro et al. determined that grand multiparity increased preterm birth risk (AOR 1.28; Cl: 1.05-1.56). Similarly, Koullali et al. reported that preterm birth risk increased in pregnant women who were having their fifth pregnancy (OR 1.26; 95\% Cl: 1.13-1.41) compared to pregnant women having their second pregnancy $(35,36)$. However, it has not yet been fully understood how parity affects the incidence of preterm births in terms of its biological mechanism, and studies carried out on the relationship between high parity and adverse pregnancy outcomes have pointed to conflicting results (37). A systematic review performed in 2010 demonstrated that grand multiparity and great grand multiparity were not associated with increased preterm birth risk (OR 0.96, 95\% $\mathrm{Cl} 0.77,1.19$ and $\mathrm{OR}$ $1.32,95 \% \mathrm{Cl}: 0.61-2.83)$ (38). A study in China determined that multiparity reduced the risk of preterm labor in comparison to nulliparity (ARR 0.91, 95\% Cl: 0.89-0.93) (39). Chen et al. showed that nulliparity increased the risk of all stages of preterm labor 1.55 times in comparison to multiparity, whereas Dahman similarly stated that it increased this risk 2.08 (respectively, OR 1.55, 95\% Cl: 1.52-1.59 and OR 2.08, p<0.002) $(40,41)$. 


\section{Limitations}

There were some limitations in our study. As our study was record-based and relied on recorded data, there may have been errors in data entry related to the pregnant women. In our retrospective study, we could not obtain data on social factors that might have affected preterm labor such as education and employment status. We also did not have data on exposure duration and severity of some risk factors that were determined (anemia, smoking), so, this may have prevented us from obtaining definitive results regarding the causes of preterm labor.

\section{CONCLUSION}

The prevalence of preterm labor, which is a risk factor, in the pregnant women who were included in this study was found to be higher than the prevalence of preterm birth determined across Turkey. In our study, in compliance with our hypotheses, it was observed that the risk of preterm labor increased in cases of anemia in pregnant women and pregnancies induced by assistive reproductive techniques. In future studies, investigating the prevalence of preterm labor based on different types of anemia and different types of assistive reproductive techniques will help us understand the etiology of preterm labor in more detail and prevent it.

Ethics Committee Approval: This study was approved by the Ethics Committee of Batman Regional State Hospital (Date: 10.06.2019, No: 200)

Peer Review: Externally peer-reviewed.

Author Contributions: Conception/Design of Study- S.P.Y., C.B.; Data Acquisition- C.B.; Data Analysis/Interpretation- C.B.; Drafting Manuscript- S.P.Y., C.B.; Critical Revision of ManuscriptS.P.Y., C.B.; Approval and Accountability- S.P.Y., C.B.

Conflict of Interest: Authors declared no conflict of interest

Financial Disclosure: Authors declared no financial support.

\section{REFERENCES}

1. Aydemir H, Hazar HU. Low risk, risk, and high risk pregnancies and the role of midwives. Gümüşhane Univ J Heal Sci 2014;2(8):15-33.

2. World Health Organization. Maternal mortality 2017. (cited 2021 June 5). Available from: https://www.who.int/newsroom/fact-sheets/detail/maternal-mortality.

3. Doğum Öncesi Bakım Yönetim Rehberi. Ankara; 2018. 1-48 p. (cited 2021 June 5). Available from: https:// khgmsaglikhizmetleridb.saglik.gov.tr/Eklenti/28085/0/ dogumoncesibakimyonetimrehberipdf.pdf.

4. Temu TB, Masenga G, Obure J, Mosha D, Mahande MJ. Maternal and obstetric risk factors associated with preterm birth at a referral hospital in northern-eastern Tanzania. Asian Pacific J Reprod 2016;(5):365-70. [CrossRef]
5. Zeitlin J, Szamotulska K, Drewniak N, Mohangoo AD, Chalmers J, Sakkeus L, et al. Preterm birth time trends in Europe: A study of 19 countries. BJOG An Int J Obstet Gynaecol 2013;(120):1356-65. [CrossRef]

6. Ooki S. The effect of an increase in the rate of multiple births on Low-Birth-Weight and preterm deliveries during 1975-2008. J Epidemiol 2010;(20):480-8. [CrossRef]

7. Blencowe H, Cousens S, Chou D, Oestergaard M, Say L, Moller AB, et al. World Health Organization Born Too Soon: The global epidemiology of 15 million preterm births. Reprod Health 2013;10(1):6-9. (cited 2021 June 5). Available from: http://www.who.int/pmnch/media/ news/2012/201204_borntoosoon_countryranking.pdf [CrossRef]

8. Alijahan R, Hazrati S, Mirzarahimi M, Pourfarzi F, Hadi PA. Prevalence and risk factors associated with preterm birth in Ardabil, Iran. Iran J Reprod Med 2014;(12):47-56.

9. Rahman MM, Abe SK, Rahman MS, Kanda M, Narita S, Bilano $V$, et al. Maternal anemia and risk of adverse birth and health outcomes in low- and middle-income countries: Systematic review and meta-analysis. Am J Clin Nutr 2016;(103):495-504. [CrossRef]

10. Ege E, Akın B, Altuntu K, Arı̈̈z A, Koçoğlu D. Prevelance of spontaneus preterm birth and related factors. TJOD Derg 2009;(6):197-205.

11. Altay MM, Bayram M, Biri AA, Büyükbayrak EE, Deren Ö, Ercan $F$, et al. Guideline on Preterm Labor and Delivery by the Society of Specialists in Perinatology (Perinatoloji Uzmanları Derneği-PUDER), Turkey. Journal of Clinical Obstetrics \& Gynecology 2020;30(3):118-30. [CrossRef]

12. Col-Araz N. Evaluation of factors affecting birth weight and preterm birth in southern Turkey. J Pak Med Assoc 2013;(63):459-62.

13. Vogel JP, Chawanpaiboon S, Moller AB, Watananirun K, Bonet M, Lumbiganon P. The global epidemiology of preterm birth. Best Pract Res Clin Obstet Gynaecol 2018;(52):3-12. [CrossRef]

14. Centers for Disease Control and Prevention. Preterm Birth in the United States. (cited 2021 June 5). Available from: https://www.cdc.gov/reproductivehealth/features/ premature-birth/index.html.

15. Baer RJ, Mclemore MR, Adler N, Oltman SP, Brittany D, Kuppermann $\mathrm{M}$, et al. Pre-pregnancy or first-trimester risk scoring to identify women at high risk of preterm birth. Eur J Obs Gynecol Reprod Biol 2018;(231):235-40. [CrossRef]

16. Bird AL, Grant CC, Bandara DK, Mohal J, Atatoa-Carr $P E$, Wise MR, et al. Maternal health in pregnancy and associations with adverse birth outcomes: Evidence from Growing Up in New Zealand. Aust New Zeal J Obstet Gynaecol 2017;(57):16-24. [CrossRef]

17. Offiah I, ODonoghue K, Kenny L. Clinical Risk Factors for Preterm Birth. In: Morrison JC editor. Preterm Birth - Mother Child. Shanghai, China: Intech Publishing; 2012 p.74-94. [CrossRef]

18. Ananth CV, Vintzileos AM. Epidemiology of preterm birth and its clinical subtypes. J Matern Neonatal Med 2006;(19):773-82. [CrossRef]

19. Wen SW, Smith G, Yang Q, Walker M. Epidemiology of preterm birth and neonatal outcome. Semin Fetal Neonatal Med 2004;(9):429-35. [CrossRef] 
20. Moini A, Shiva M, Arabipoor A, Hosseini R, Chehrazi M, Sadeghi M. Obstetric and neonatal outcomes of twin pregnancies conceived by assisted reproductive technology compared with twin pregnancies conceived spontaneously: A prospective follow-up study. Eur J Obstet Gynecol Reprod Biol 2012;(165):29-32. [CrossRef]

21. Kissin DM, Jamieson DJ, Barfield WD. Monitoring Health Outcomes of Assisted Reproductive Technology. N Engl J Med 2014;(371):91-3. [CrossRef]

22. Martin JA, Hamilton BE, Osterman MJK, Curtin SC, Mathews TJ. Births: final data for 2012. Natl Vital Stat Rep 2013; 62(9):1-68.

23. Cin JB, Sheng XQ, Wang $H$, Chen GC, Yang J, Yu H, et al. Worldwide prevalence of adverse pregnancy outcomes associated with in vitro fertilization/intracytoplasmic sperm injection among multiple births: a systematic review and meta-analysis based on cohort studies. Arch Gynecol Obstet 2017;(295):577-97. [CrossRef]

24. Luke B, Brown MB, Wantman E, Seifer DB, Sparks AT, Lin $P C$, et al. Risk of prematurity and infant morbidity and mortality by maternal fertility status and plurality. J Assist Reprod Genet 2019;36(1):121-38. [CrossRef]

25. Stern JE, Liu CL, Cabral HJ, Richards EG, Coddington CC, Hwang S, et al. Birth outcomes of singleton vaginal deliveries to ART-treated, subfertile, and fertile primiparous women. J Assist Reprod Genet 2018;35(9):1585-93. [CrossRef]

26. Luke B, Gopal D, Cabral H, Stern JE, Diop H. Pregnancy, birth, and infant outcomes by maternal fertility status: the Massachusetts Outcomes Study of Assisted Reproductive Technology. Am J Obstet Gynecol 2017;217(327);1-14. [CrossRef]

27. Cavoretto P, Candiani M, Giorgione V, Inversetti A, AbuSaba MM, Tiberio F, et al. Risk of spontaneous preterm birth in singleton pregnancies conceived after IVF/ICSI treatment: meta-analysis of cohort studies. Ultrasound Obstet Gynecol 2018;51(1):43-53. [CrossRef]

28. Haider BA, Olofin I, Wang M, Spiegelman D, Ezzati M, Fawzi WW. Nutrition Impact Model Study Group (aneamia). Anaemia, prenatal iron use, and risk of adverse pregnancy outcomes: systematic review and meta-analysis. BMJ 2013;346:f3443. [CrossRef]

29. Rahmati S, Azami M, Badfar G, Parizad N, Sayehmiri K. The relationship between maternal anemia during pregnancy with preterm birth: a systematic review and meta-analysis. J Matern Neonatal Med 2020;(33):2679-89. [CrossRef]
30. Hansen M, Singh G, Barzi F, Brunette R, Howarth T, Morris P, et al. Maternal anaemia in pregnancy: a significantly greater risk factor for anaemia in australian aboriginal children than low birth weight or prematurity. Matern Child Health J 2020;24(8):979-85. [CrossRef]

31. Chu FC, Shaw SW, Lo LM, Hsieh TT, Hung TH. Association between maternal anemia at admission for delivery and adverse perinatal outcomes. J Chin Med Assoc 2020;83(4):402-7. [CrossRef]

32. Finkelstein $\mathrm{JL}$, Kurpad AV, Bose B, Thomas $T$, Srinivasan $\mathrm{K}$, Duggan C. Anaemia and iron deficiency in pregnancy and adverse perinatal outcomes in Southern India. Eur J Clin Nutr 2020;74(1):112-25. [CrossRef]

33. Uçkan K, Çeleğen I, Uçkan T. Evaluation of the Effect of Pregnancy Anemia on Perinatal Results. Kafkas J Med Sci 2020;(10):131-5. [CrossRef]

34. Ardic C, Usta O, Omar E, Yıldız C, Memis E, Öztürk GE. Relationship between anaemia during pregnancy and preterm delivery, Journal of Obstetrics and Gynaecology 2019;39(7):903-06. [CrossRef]

35. Muniro Z, Tarimo CS, Mahande MJ, Maro E, McHome B. Grand multiparity as a predictor of adverse pregnancy outcome among women who delivered at a tertiary hospital in Northern Tanzania. BMC Pregnancy Childbirth 2019;19:222. [CrossRef]

36. Koullali B, Van Zijl MD, Kazemier BM, Oudijk MA, Mol BWJ, Pajkrt E, et al. The association between parity and spontaneous preterm birth: A population based study. BMC Pregnancy Childbirth 2020;20:233. [CrossRef]

37. Aliyu MH, Jolly PE, Ehiri JE, Salihu HM. High parity and adverse birth outcomes: Exploring the maze. Birth 2005;(32):45-59. [CrossRef]

38. Shah PS. Parity and low birth weight and preterm birth: $A$ systematic review and meta-analyses. Acta Obstet Gynecol Scand 2010;(89):862-75. [CrossRef]

39. Lin L, Lu C, Chen W, Li C, Guo VY. Parity and the risks of adverse birth outcomes: a retrospective study among Chinese. BMC Pregnancy Childbirth 2021;21(1):257. [CrossRef]

40. Chen KH, Chen IC, Yang YC, Chen KT. The trends and associated factors of preterm deliveries from 2001 to 2011 in Taiwan. Medicine (Baltimore) 2019;98(13):e15060. [CrossRef]

41. Dahman HAB. Risk factors associated with preterm birth: a retrospective study in Mukalla Maternity and Childhood Hospital, Hadhramout Coast/Yemen. Sudan J Paediatr 2020;20(2):99-110. [CrossRef] 